\title{
Evaluation of the yield, molar mass of exopolysaccharides, and rheological properties of gels formed during fermentation of milk by Streptococcus thermophilus strains St-143 and ST-10255y
}

\author{
Som N. Khanal ${ }^{*}$ and John. A. Lucey ${ }^{1}$ \\ *Department of Food Science, and \\ †Wisconsin Center for Dairy Research, University of Wisconsin-Madison, 1605 Linden Drive, Madison 53706
}

\begin{abstract}
The yield and chemical structures of exopolysaccharides (EPS) produced by many strains of Streptococcus thermophilus have been characterized. However, the kinetics (or production profile) for EPS during milk fermentation is not clear. In this study, we investigated whether any differences existed in the yield and molar mass of EPS when milk was fermented at the same acidification rate by 2 strains of $S$. thermophilus (St-143 and ST-10255y). The type of EPS produced by these 2 strains is different. Milk samples were analyzed for EPS concentration every 30 min during a fermentation period of 270 min (final $\mathrm{pH} 4.5$ ) by using a modified quantification method, which was faster and validated for its recovery of added EPS. Rheological properties of milks during fermentation were also analyzed using small-strain dynamic oscillatory rheology. For the determination of molar mass, EPS extracts were isolated by ultrafiltration of whey obtained during fermentation of milk to $\mathrm{pH}$ values $5.2,4.9,4.7$, and 4.5 , and molar mass was analyzed using size-exclusion chromatographymulti-angle laser light scattering. During fermentation, both strains appeared to start producing significant amounts of EPS after about $\sim 150 \mathrm{~min}$, which corresponded to $\mathrm{pH} \sim 5.3$, which was close to the point of gelation. During the remainder of the fermentation process (150-270 min), the EPS concentration from strains St-143 and ST-10255y significantly increased from 30 to $72 \mathrm{mg} / \mathrm{L}$ and from 26 to $56 \mathrm{mg} / \mathrm{L}$, respectively. The quantity of EPS recovered by our modified method was estimated to represent $\sim 60 \%$ of the total EPS added to milk. The molar mass of EPS produced by both strains appeared to slightly decrease during fermentation. At $\mathrm{pH}$ 5.2, EPS from St-143 and ST-10255y had molar masses of $2.9 \times 10^{6}$ and $1.4 \times 10^{6} \mathrm{~g} / \mathrm{mol}$, respectively,
\end{abstract}

Received March 4, 2017.

Accepted May 6, 2017.

${ }^{1}$ Corresponding author: jlucey@cdr.wisc.edu which decreased to $1.6 \times 10^{6}$ and $0.8 \times 10^{6} \mathrm{~g} / \mathrm{mol}$, respectively, when the $\mathrm{pH}$ of milk was 4.5 . Distinct differences were apparent in the rheological properties of gels fermented by the 2 strains. At the end of fermentation, St-143 fermented milk had weaker gels with storage modulus $\left(\mathrm{G}^{\prime}\right)$ value at $\mathrm{pH} 4.6$ of $26 \mathrm{~Pa}$, whereas gels made with ST-10255y were stiffer with a $G^{\prime}$ value at pH 4.6 of 82 Pa. For St-143 gels, maximum loss tangent $\left(\mathrm{LT}_{\max }\right)$ values were higher $(0.50)$ and occurred earlier (at a higher $\mathrm{pH}$ value) than the $\mathrm{LT}_{\max }$ values $(0.46)$ for gels from ST-10255y strain. Because the fermentation conditions were identical for both strains, the observed changes in rheological properties could be due to the differences in chemical structures and molar mass of the EPS produced by these $2 S$. thermophilus strains.

Key words: yogurt, exopolysaccharides, rheology, Streptococcus thermophilus

\section{INTRODUCTION}

Streptococcus thermophilus is 1 of the 2 species of lactic acid bacteria (LAB) that are extensively used in fermented milk products such as yogurt. Some strains of $S$. thermophilus have the ability to synthesize large polymeric carbohydrates, called exopolysaccharides (EPS). The presence of significant quantities of EPS in fermented milks is indicated by a sticky or stringy appearance termed "ropiness" when these gels are stirred (De Vuyst and Degeest, 1999; De Vuyst and De Vin, 2007). Streptococcus thermophilus strains can generally synthesize 2 types of EPS. One type is synthesized inside the cell, and when released from the cell, the EPS remains attached to the exterior of cell, forming a capsule; hence, it is called capsular EPS. Another type of EPS is liberated into the medium and provides a ropy or slimy characteristic; hence, this type is called ropy EPS (Low et al., 1998; Broadbent et al., 2003).

The ability of $S$. thermophilus strains to produce EPS has been studied since the 1980s. Giraffa and Bergère (1987) reported on 3 ropy strains of S. thermophilus, namely CNRZ 404, CNRZ 783, and CNRZ 784, that 
produced 21 to $39 \mathrm{mg}$ of EPS per liter in reconstituted skim milk supplemented with additional nutrients. Another 3 ropy strains of $S$. thermophilus were reported to produce 29 to $185 \mathrm{mg}$ of EPS per liter of reconstituted skim milk, and the EPS content was greatly reduced when isolated EPS was subjected to protein hydrolysis followed by dialysis (Cerning et al., 1988). At the present time, at least 60 strains of $S$. thermophilus that produce EPS have been studied during the fermentation of milk, and the yield of EPS obtained from these various strains varies markedly $(8-290 \mathrm{mg} / \mathrm{L})$ from strain to strain (Giraffa and Bergère, 1987; Cerning et al., 1988; De Vuyst et al., 2001; Broadbent et al., 2003; Pachekrepapol et al., 2017).

Different methods have been used for the isolation and quantification of EPS from various types of fermentation media. To isolate EPS from milk, removal of milk protein has been carried out by (optional) enzymatic hydrolysis of protein, trichloroacetic acid (TCA) precipitation, or both. To isolate EPS from the resulting supernatant, ethanol, acetone, or both have been used; ethanol is the most commonly used solvent (Ruas-Madiedo and de los Reyes-Gavilán, 2005; Leroy and De Vuyst, 2016). Different strains may produce different amounts of EPS in milk depending on the availability of nutrients and fermentation conditions; the EPS yield is also affected by the methods used for isolation and quantification of EPS (Leroy and De Vuyst, 2016). Giraffa and Bergère (1987) and Cerning et al. (1988) isolated EPS by first hydrolyzing milk protein using Pronase enzyme after the fermentation was completed, followed by cell removal via centrifugation and multi-step precipitation of EPS by ethanol. Initially, Cerning et al. (1988) determined the EPS content by the phenol sulfuric acid method. When EPS was further subjected to dialysis, the net EPS content in the extract was markedly reduced, indicating ethanol precipitation may have been insufficient to remove all the small sugars, particularly lactose, that could interfere with the estimation of the actual quantity of EPS (Cerning et al., 1988). In another study by Faber et al. (1998), the yield of EPS was determined by removing milk protein by TCA precipitation and extensive dialysis of the supernatant. The EPS content in the supernatant was determined by high-performance gel permeation chromatography, using dextran standards. De Vuyst et al. (2003) used a method consisting of protein removal by TCA precipitation, EPS isolation by acetone precipitation, and residual protein precipitation by TCA followed by re-precipitation by acetone to finally isolate EPS free of small sugars and protein. The yields of EPS reported for the $S$. thermophilus strains used by De Vuyst et al. (2003) and Vaningelgem et al. (2004) were higher in comparison to other reports.
Not many reports exist for the yield of EPS from the same strains of $S$. thermophilus quantified using different isolation methods. Rimada and Abraham (2003) compared 8 different methods for the isolation and quantification of kefiran (the type of EPS in kefir) from milk-based media and found marked differences in the kefiran yields. Yields were higher for methods that used heating as an initial step and when multiple ethanol precipitation steps were used. Trichloroacetic acid precipitation at the beginning of the isolation procedure caused an almost 50\% loss in EPS yield (Rimada and Abraham, 2003). Recently, EPS from S. thermophilus strains St-143 and DGCC 7710 was isolated by 2 different methods. In the study by Pachekrepapol et al. (2017), milk protein was removed from the fermented milk by TCA precipitation, and EPS was isolated from the supernatant by repeated ethanol precipitation followed by removal of small sugars by dialysis. The EPS content in freeze-dried isolate produced by DGCC 7710 and St-143 strains were 77 and $66 \mathrm{mg}$ of glucose equivalent $(\mathbf{G E}) / \mathrm{L}$ of medium, respectively (Pachekrepapol et al., 2017). Mende et al. (2012) also isolated this EPS by enzymatic hydrolysis, TCA precipitation of protein followed by precipitation with acetone and dialysis. The EPS contents in their dried sample were 110 and $137 \mathrm{mg}$ of GE/L for the strains St-143 and DCGG7710, respectively (Mende et al., 2012). Goh et al. (2005) evaluated 2 methods of EPS isolation from synthetic media. In one method, protein was hydrolyzed by Pronase and precipitated by TCA. The resultant supernatant was dialyzed for $48 \mathrm{~h}$. In another method (Goh et al., 2005), cells were removed by centrifugation and EPS was directly precipitated by ethanol and dialyzed for $48 \mathrm{~h}$. A comparison of these 2 methods revealed a marked difference in EPS yields.

Since Doco et al. (1990) first determined the molar mass of EPS isolated from $S$. thermophilus strains, at least 40 strains of this species have been investigated for the molar masses of their isolated EPS. The reported molar mass values of the different EPS isolated from $S$. thermophilus strains have varied greatly. More than 26 $S$. thermophilus strains have been reported to produce EPS with molar mass greater than $1 \times 10^{6} \mathrm{~g} / \mathrm{mol}$. At least 14 strains have been reported to produce EPS with molar mass less than $1 \times 10^{6} \mathrm{~g} / \mathrm{mol}$, whereas 10 strains have been reported to produce 2 distinct EPS fractions, one type having molar mass values larger than $1 \times 10^{6} \mathrm{~g} / \mathrm{mol}$ and another fraction with molar mass values below $1 \times 10^{6} \mathrm{~g} / \mathrm{mol}$ (Doco et al., 1990; Lemoine et al., 1997; Faber et al., 1998; Marshall et al., 2001; Vaningelgem et al., 2004). The molar mass determination techniques were mainly based on gel filtration chromatography, which compared the molar mass of EPS with standards (dextran) of known molar mass 
values. In more recent studies (e.g., Pachekrepapol et al., 2017), size-exclusion chromatography coupled with multi-angle laser light scattering (SEC-MALLS) has been used, which is a method that can directly measure the molar mass of polymers.

Reviewing the different methods for the isolation and yield determination of EPS, 2 major limitations of the various methods are obvious. Most of the EPS isolation and purification methods are very time consuming. In addition, uncertainties are present in these methods about the ability to recover the total amount of EPS present in a milk-based medium (Leroy and De Vuyst, 2016). Moreover, all the milk studies conducted to date on the production of EPS from $S$. thermophilus were focused on the final EPS yields (i.e., at the end of fermentation). Information on quantities and structural properties of EPS produced during the fermentation period (i.e., the kinetics of EPS production) are limited.

In this study, our objective was to determine the EPS concentrations at regular intervals during the fermentation of milk by using a relatively quicker quantification method, which was validated for its recovery of added EPS. Another objective was to determine the physical properties, including molar mass, size, and the polydispersity of EPS produced during fermentation, and to understand the relationship between the physical properties of EPS and the rheological properties of fermented milk gels.

\section{MATERIALS AND METHODS}

\section{Reconstitution of Milk}

Low heat nonfat dry milk powder was obtained from Dairy America (Fresno, CA) and the whey protein nitrogen index was determined as $7.56 \mathrm{mg}$ of undenatured whey protein per gram of powder, using the method suggested by Wehr and Frank (2004). Milk was reconstituted by dispersing $12 \mathrm{~g}$ of powder in $100 \mathrm{~g}$ of deionized water and stirring at room temperature for 3 h. Reconstituted milk was heated at $85^{\circ} \mathrm{C}$ for $30 \mathrm{~min}$ in a water bath, cooled to $\sim 5^{\circ} \mathrm{C}$, and stored in refrigerator for up to $24 \mathrm{~h}$ before use.

\section{Preparation of EPS Cultures}

Two EPS-producing S. thermophilus strains, St-143 and ST-10255y, obtained from Chr. Hansen (Hørsholm, Denmark) were used for this study. Both strains are known to produce EPS when grown in a milk medium. These 2 strains were selected based on the differences in their likely EPS yields as well as differences in repeating unit structures (Pachekrepapol et al., 2017).
Strain St-143 has been reported to produce EPS yields ranging from 65 to $110 \mathrm{mg}$ of $\mathrm{GE} / \mathrm{L}$, whereas strain ST$10255 \mathrm{y}$ has been reported to produce $27 \mathrm{mg}$ of $\mathrm{GE} / \mathrm{L}$ of EPS when grown in reconstituted milk (Mende et al., 2012; Pachekrepapol et al., 2017). Strain St-143 has been reported to produce EPS with a hexasaccharide repeating unit, whereas the ST-10255y EPS repeating unit was reported to be tetrasaccharide (Pachekrepapol et al., 2017).

Reconstituted skim milk, prepared as above, was autoclaved for $15 \mathrm{~min}$ and cooled to $40^{\circ} \mathrm{C}$. Frozen cultures $\left(-80^{\circ} \mathrm{C}\right)$ were thawed, and $2 \mathrm{~mL}$ of these cultures was inoculated into $500 \mathrm{~mL}$ of the sterilized skim milk at $40^{\circ} \mathrm{C}$ and incubated at $40^{\circ} \mathrm{C}$ until the milk gelled $(\mathrm{pH}$ $\sim 5.0$ ). The fermented milk was aseptically filled into 5 -mL sterile cryogenic vials (Fisher Scientific, Pittsburgh, PA) and stored frozen $\left(-80^{\circ} \mathrm{C}\right)$ to use as a stock culture. Starter culture was prepared immediately before use by inoculating $1 \mathrm{~mL}$ of the thawed stock culture into $80 \mathrm{~mL}$ of the sterilized milk at $40^{\circ} \mathrm{C}$. Inoculated milk was incubated at $40^{\circ} \mathrm{C}$ for $\sim 4 \mathrm{~h}(\mathrm{pH} \sim 5.0)$.

\section{Fermentation of Milk and Monitoring of $\mathrm{pH}$}

Both of these strains had different abilities to acidify milk, mainly due to minor differences in their proteolytic activity. To obtain similar acidification rates, the milk used for fermentation by St-143 and ST-10255y strains was supplemented with $3.0 \%$ (wt/wt) and $0.2 \%$ (wt/wt) peptone, respectively, as suggested by Pachekrepapol et al. (2017). After cooling to $40^{\circ} \mathrm{C}, 500 \mathrm{~mL}$ of milk was inoculated with $2 \%$ ( vol/vol) of the freshly prepared starter culture of each individual strain. Exactly $50 \mathrm{~mL}$ of inoculated milk was poured into sterile 250-mL polycarbonate centrifuge bottles (Fisher Scientific, Waltham, MA), and bottles were closed with an air-sealed cap before incubation at $40^{\circ} \mathrm{C}$ in a Precision Low Temperature incubator (Thermo Fisher Scientific, Marietta, $\mathrm{OH}$ ). To monitor the change in $\mathrm{pH}$ during fermentation, 50 to $70 \mathrm{~mL}$ of milk was poured in a 100$\mathrm{mL}$ glass vial and a $\mathrm{pH}$ probe of a computer-connected model PCM 700 Orion Sensor Link system (Orion Research Inc., Beverly, MA) was immersed into the milk. The surface of the milk in the vials was covered with vegetable oil to make a similar (anaerobic) environment as used in the measurement of rheological properties. The system recorded $\mathrm{pH}$ values every 5 min during fermentation.

\section{Rheological Properties of Milk During Fermentation}

To determine the rheological properties of milk gels during fermentation, a Paar Physica rheometer, MCR 
301 (Anton Paar, Ashland, VA) was used. Nondestructive, small-strain dynamic oscillatory measurements were performed with a cup-and-bob geometry (CC27SN23928) consisting of 2 coaxial cylinders with diameters of 26.7 and $28.9 \mathrm{~mm}$. The temperature of the system was set at $40^{\circ} \mathrm{C}$. Inoculated milk was aseptically transferred to the rheometer. The milk surface of the measuring geometry was covered with vegetable oil to avoid evaporation. An oscillatory frequency of $1 \mathrm{~Hz}$, with $0.5 \%$ strain, was applied to milk during the entire fermentation period. Data for storage modulus $\left(\mathbf{G}^{\prime}\right)$ and loss tangent $(\mathbf{L T})$ were recorded every 5 min until the end of fermentation (270 min, $\mathrm{pH} \sim 4.5$ ). During fermentation, milk was considered to be gelled when the $\mathrm{G}^{\prime}$ values of the gels exceeded $1 \mathrm{~Pa}$ (Lucey et al., 1998a).

\section{Determination of EPS Concentration During Milk Fermentation}

The EPS content of fermented milk was determined using the method for EPS quantification described by Enikeev (2012) with some modifications. Originally, this method was used to determine the EPS content in kefir. This method was modified to standardize conditions and steps and to determine its efficiency to recover added EPS from milk.

Modification of EPS Determination Method and Recovery of EPS. Exactly $50 \mathrm{~mL}$ of milk containing EPS was transferred into 250-mL Fisherbrand polycarbonate centrifuge bottles (Fisher Scientific, Pittsburgh, $\mathrm{PA}$ ), and the $\mathrm{pH}$ value was adjusted to $\mathrm{pH}$ $\sim 4.6$ (if necessary) by the addition of $10 \%$ ( $\mathrm{vol} / \mathrm{vol}$ ) lactic acid solution. Milk was heated at $98^{\circ} \mathrm{C}$ in a water bath for 30 min with constant stirring to inactivate the culture and precipitate proteins. The heated milk was then centrifuged at $6,000 \times g$ for $15 \mathrm{~min}$ at $25^{\circ} \mathrm{C}$. The pellet was discarded, and the supernatant was treated with $5 \mathrm{~mL}$ of $12 \mathrm{M} \mathrm{HCl}$ at $70^{\circ} \mathrm{C}$, cooled, and neutralized to $\mathrm{pH} 7.0$ by the addition of $20 \%$ (wt/vol) $\mathrm{NaOH}$. This supernatant was again centrifuged at $6,000 \times g$ for 15 min at $25^{\circ} \mathrm{C}$, and the supernatant was treated with a double volume of cold $\left(-20^{\circ} \mathrm{C}\right)$ absolute ethanol and kept at $-20^{\circ} \mathrm{C}$ for $3 \mathrm{~h}$ to facilitate precipitation of EPS. After precipitation, the entire contents of each bottle was centrifuged at $16,000 \times g$ for $20 \mathrm{~min}$ at $4^{\circ} \mathrm{C}$, and the supernatant was discarded. The pellet was dissolved in $40 \mathrm{~mL}$ of $55^{\circ} \mathrm{C}$ deionized water, and the solution was centrifuged at $6,000 \times g$ for $15 \mathrm{~min}$ at $25^{\circ} \mathrm{C}$ to remove undissolved impurities as a pellet. The supernatant was treated with equal volume of cold absolute ethanol and kept at $-20^{\circ} \mathrm{C}$ for $3 \mathrm{~h}$. The supernatant was centrifuged at $16,000 \times g$ for $20 \mathrm{~min}$ at $4^{\circ} \mathrm{C}$, and the supernatant was discarded. The pellet was washed twice with $50 \%$ cold ethanol to remove any remaining small sugars and dissolved in $40 \mathrm{~mL}$ of water at $55^{\circ} \mathrm{C}$. Finally, the aliquot was centrifuged at $6,000 \times g$ for $15 \mathrm{~min}$ at $25^{\circ} \mathrm{C}$ to remove insoluble materials, and the volume of the supernatant was adjusted to $50 \mathrm{~mL}$.

To test the efficiency of the extraction method, known concentrations of model EPS [i.e., dextran (Sigma-Aldrich, St. Louis, MO) with an average molar mass of $\left.2 \times 10^{6} \mathrm{~g} / \mathrm{mol}\right]$ was added to (unfermented) milk at various dextran concentrations ranging from 0 to $800 \mathrm{mg} / \mathrm{L}$. The amount of dextran in these milks was determined by our modified Enikeev method.

Recovery of added EPS by the modified Enikeev method was calculated using the following equation:

$$
\begin{aligned}
& \text { Recovery }(\%)= \\
& \frac{\text { Measured dextran by modified method }(\mathrm{mg} / \mathrm{L})}{\text { Added dextran to milk }(\mathrm{mg} / \mathrm{L})} \times 100 \text {. }
\end{aligned}
$$

To ensure that we had removed all the small sugars, the lactose, glucose, and galactose contents in the final EPS aliquot were determined by an HPLC method (Mullin and Emmons, 1997). Protein content in the final EPS aliquot was also determined by bicinchoninic acid assay using the Pierce BCA Protein Assay Kit (Pierce Biotechnology, Rockford, IL). The amount of EPS synthesized by the $S$. thermophilus strains in milk during the fermentation period of 270 min was determined at 30 -min intervals. Exactly $50 \mathrm{~mL}$ of milk (in $250-\mathrm{mL}$ centrifuge bottles) was fermented for each interval and subjected to EPS determination.

Quantification of EPS Concentration. The phenol sulfuric method (Dubois et al., 1956), with some modifications, was used for the determination of EPS (sugar) contents in the final EPS aliquots. A standard curve for the phenolic sulfuric acid method was obtained using various known concentrations of dextran (SigmaAldrich); the dextran had an average molar mass of $2 \times$ $10^{6} \mathrm{~g} / \mathrm{mol}$, which was a similar molar mass to the EPS produced by $S$. thermophilus strains. An aliquot was also extracted from an inoculated (but not fermented) milk sample to use as the blank for phenol sulfuric acid analysis of the EPS extracts from fermented samples.

\section{Determination of Molar Mass of Isolated EPS}

In determining the molar mass of EPS, a concern existed that precipitation of EPS during extraction with ethanol, in conjunction with lyophilization, could alter its measured molar mass when rehydrated (Pachekre- 
papol et al., 2017). Therefore, we instead isolated the EPS by ultrafiltration. One liter of reconstituted skim milk with added peptone was prepared as described earlier, and $30 \mathrm{~mL}$ of starter culture was added into this milk. Inoculated milk was incubated at $40^{\circ} \mathrm{C}$ until $\mathrm{pH}$ values of $5.2,4.9,4.7$, and 4.5 . When milk reached these selected $\mathrm{pH}$ values, fermentation was stopped by heating milk at $85^{\circ} \mathrm{C}$ for 10 min with constant stirring. The mixture was cooled and centrifuged at $6,000 \times g$ for $10 \mathrm{~min}$ at $25^{\circ} \mathrm{C}$, and the supernatant (whey) was collected. The pellet (curd) was suspended into 500 $\mathrm{mL}$ of water at $50^{\circ} \mathrm{C}$, cooled to $25^{\circ} \mathrm{C}$, and centrifuged again. The supernatant was collected, and the pellet was discarded. The 2 supernatants were pooled and ultrafiltered through 100-kDa Prep/Scale TFF ultrafiltration membrane cartridges (Millipore, Bedford, MA). The permeate was discarded, and the retentate was diafiltered with distilled water up to 12 times to remove small sugars (as indicated by a minimal carbohydrate content of the permeate by the phenol sulfuric acid analysis method). After ultrafiltration, the retentate was collected and $\mathrm{pH}$ was adjusted to 4.6 by addition of $0.1 \mathrm{~N} \mathrm{HCl}$. The retentate was then heated without stirring at $80^{\circ} \mathrm{C}$ for $5 \mathrm{~min}$ and centrifuged at $10,000 \times$ $g$ for 15 min at $25^{\circ} \mathrm{C}$. For the EPS sample from strain ST-10255y, residual protein content in the supernatant was removed by $12 \%$ TCA precipitation followed by repeated ultrafiltration to remove any residual TCA. Final retentate was concentrated to one fifth of its volume by using an Amicon stirred ultrafiltration cell (Millipore) with a $10-\mathrm{kDa}$ Millipore disc membrane (Millipore).

Next, SEC-MALLS was used to determine the molar mass of the isolated EPS, as described by Wang and Lucey (2003). The SEC system consisted of Waters 600 HPLC unit (Waters, Milford, MA) connected to SEC Superose 12HR 10/300 and 6HR 10/300 columns connected in series (Amersham Pharmacia Biotech AB, Uppsala, Sweden). The system consisted of 3 detectors, namely a model 2998 photodiode array detector operating at $280 \mathrm{~nm}$ (Waters), a DAWN EOS MALLS photometer system (Wyatt Technology, Santa Barbara, $\mathrm{CA})$ fitted with a helium neon-laser $(\lambda=690 \mathrm{~nm})$ and a K-5 flow cell, and a model 2414 refractive index $(\mathbf{R I})$ detector (Waters).

The EPS extracts were first filtered using a $0.22-\mu \mathrm{m}$ syringe filter (Millipore) to remove any dust or impurities. Sample $(100 \mu \mathrm{L})$ was injected into the SEC system, which was operated at a flow rate of $0.5 \mathrm{~mL} / \mathrm{min}$. The chromatograms were analyzed for the intensities of the RI and UV signals. The peaks with higher RI signals and correspondingly low or no UV signals at $280 \mathrm{~nm}$ were confirmed as EPS peaks. Molar mass, polydisper- sity, and radius of gyration $\left(\mathbf{R}_{g}\right)$ of the EPS molecules were determined by ASTRA software version 4.73.04 (Wyatt Technology) using the Debye fitting method (Wang and Lucey, 2003). Refractive index increment value of $0.14 \mathrm{~mL} / \mathrm{g}$ was used for polysaccharides (EPS) (di Cagno et al., 2014). The SEC-MALLS system was calibrated using monomeric bovine serum albumin (molar mass of $66.4 \times 10^{3} \mathrm{~g} / \mathrm{mol}$; Sigma-Aldrich).

\section{Statistical Analysis}

Experiments for the determination of EPS yield were repeated 3 times with duplicates in each experiment (n $=6$ ). Experiments for dextran recovery and rheological properties of milk gels were also repeated at least 3 times. Experiments for molar mass determination were carried out twice. Means were compared by ANOVA and Tukey-Kramer HSD using JMP Pro 11.0 (SAS Institute Inc., Cary, NC) software with significance indicated at $P<0.05$.

\section{RESULTS}

\section{Fermentation Time and $\mathrm{pH}$}

The $\mathrm{pH}$ values during the fermentation of milk is shown in Figure 1. The initial $\mathrm{pH}$ of inoculated milk was close to 6.5 and reached $\mathrm{pH} 4.5$ after $270 \mathrm{~min}$, when fermented by both strains. Similar $\mathrm{pH}$ profiles of fermentation were observed for both strains. Until 90 min, milk pH did not noticeably change; after $150 \mathrm{~min}$, pH decreased steeply until $210 \mathrm{~min}$, when it decreased

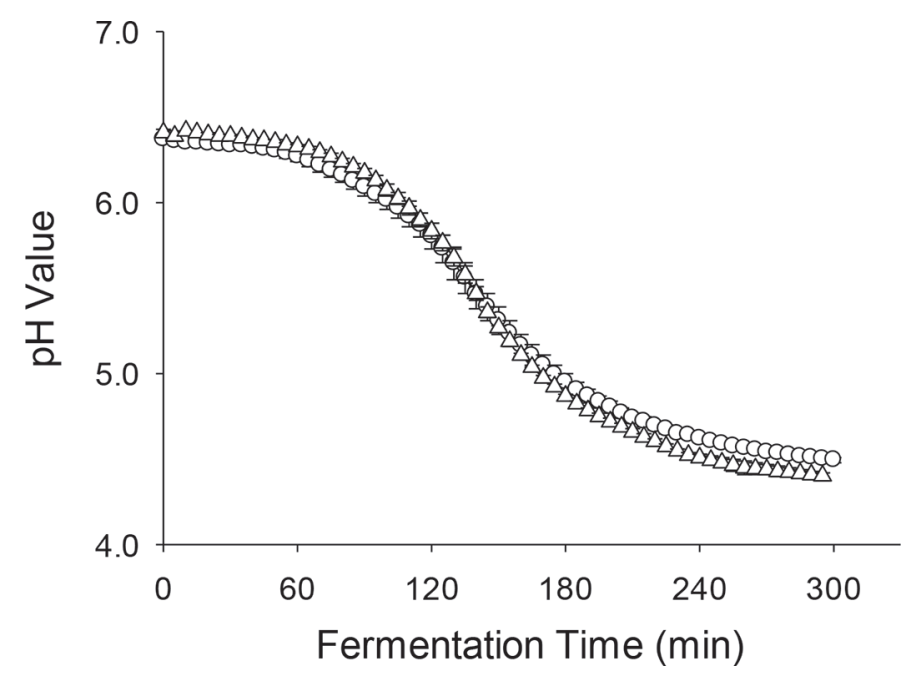

Figure 1. Change in $\mathrm{pH}$ values of milk during fermentation by Streptococcus thermophilus St-143 $(\bigcirc)$ and ST-10255y $(\Delta)$ at $40^{\circ} \mathrm{C}$. Error bars indicate standard error of means. 
Table 1. Recovery of added dextran in milk by the modified isolation method, and the lactose and protein contents in the final dextran extracts ${ }^{1}$

\begin{tabular}{lcccc}
\hline $\begin{array}{l}\text { Dextran } \\
\text { added to milk } \\
(\mathrm{mg} / \mathrm{L})\end{array}$ & $\begin{array}{c}\text { Recovered } \\
\text { dextran } \\
(\mathrm{mg} / \mathrm{L})\end{array}$ & $\begin{array}{c}\text { Recovery } \\
\text { of dextran } \\
(\%)\end{array}$ & $\begin{array}{c}\text { Lactose content in final } \\
\text { EPS }^{2} \text { extract }(\mathrm{mg} / \mathrm{L})\end{array}$ & $\begin{array}{c}\text { Protein content in final } \\
\text { EPS extract }(\mathrm{mg} / \mathrm{L})\end{array}$ \\
\hline 0 & 0.0 & 0.0 & $0.5 \pm 0.1^{\mathrm{a}}$ & $1,157 \pm 356^{\mathrm{b}}$ \\
50 & $22 \pm 3$ & $44 \pm 5^{\mathrm{b}}$ & $0.6 \pm 0.1^{\mathrm{a}}$ & $1,491 \pm 331^{\mathrm{ab}}$ \\
100 & $54 \pm 4$ & $53 \pm 4^{\mathrm{ab}}$ & $0.8 \pm 0.1^{\mathrm{a}}$ & $1,584 \pm 262^{\mathrm{a}}$ \\
200 & $97 \pm 3$ & $48 \pm 1^{\mathrm{b}}$ & $0.8 \pm 0.0^{\mathrm{a}}$ & $1,336 \pm 327^{\mathrm{ab}}$ \\
400 & $242 \pm 16$ & $60 \pm 4^{\mathrm{a}}$ & $0.6 \pm 0.1^{\mathrm{a}}$ & $1,302 \pm 222^{\mathrm{ab}}$ \\
800 & $489 \pm 35$ & $61 \pm 4^{\mathrm{a}}$ & $0.7 \pm 0.1^{\mathrm{a}}$ & $1,754 \pm 249^{\mathrm{a}}$ \\
\hline
\end{tabular}

${ }^{\mathrm{a}, \mathrm{b}}$ Different superscripts in the same column indicate significant difference $(P<0.05)$.

${ }^{1}$ Values are means \pm SEM for $n=4$ for recovery of dextran and $n=6$ for lactose and protein contents.

${ }^{2} \mathrm{EPS}=$ exopolysaccharides

relatively slowly until fermentation was stopped at $\mathrm{pH}$ values close to 4.5 .

\section{Evaluation of Modified Enikeev Method for Determination of EPS Concentration}

Recovery of Added EPS. The recovered EPS content from milk that originally contained $50 \mathrm{mg} / \mathrm{L}$ of dextran was $22 \mathrm{mg} / \mathrm{L}$, which corresponded to $44 \%$ recovery. Lower recoveries were obtained for samples containing relatively lower dextran concentration, whereas recovery exceeded $60 \%$ for milk containing more than $400 \mathrm{mg} / \mathrm{L}$ of added dextran (Table 1).

The HPLC analysis indicated that the concentrations of lactose, or simple sugars, were less than $1 \mathrm{mg} / \mathrm{L}$ (Table 1), and only trace levels of glucose and galactose (result not shown) were present in the final EPS extracts. This result indicated that the total carbohydrate contents determined for EPS extracts were not significantly affected by any potential contamination by residual lactose, glucose, or galactose. The isolated EPS (dextran) extracts were also analyzed for protein content. Regardless of the added dextran concentration in the extracts, the residual protein content varied from 1,157 to $1,753 \mathrm{mg} / \mathrm{L}$ (Table 1 ). The phenol sulfuric acid method was evaluated for any possible interference due to residual protein or ethanol, and no interferences were observed.

Yield of EPS. The yields of EPS produced by $S$. thermophilus strains St-143 and ST-10255y during fermentation of milk are shown in Figure 2b. For about the first $120 \mathrm{~min}$ of the fermentation period $(\mathrm{pH} \geq 5.9$ ), the milks fermented by either strains had no significant amount of EPS. The yield of EPS increased for both strains as the fermentation continued $(\mathrm{pH}$ decreased $<5.9)$. Final EPS yield at the end of fermentation $(\mathrm{pH}$ 4.5) was significantly higher for the strain St-143 compared with ST-10255y (Table 2, Figure 2b).

\section{Rheology of Acid Milk Gels}

The rheological properties of milk samples fermented by $S$. thermophilus strains St-143 and ST-10255y are shown in Figure 2a. The gelation point (i.e., $\mathrm{G}^{\prime}>1$ $\mathrm{Pa})$ was similar $(\sim 152 \mathrm{~min})$ for milk fermented by
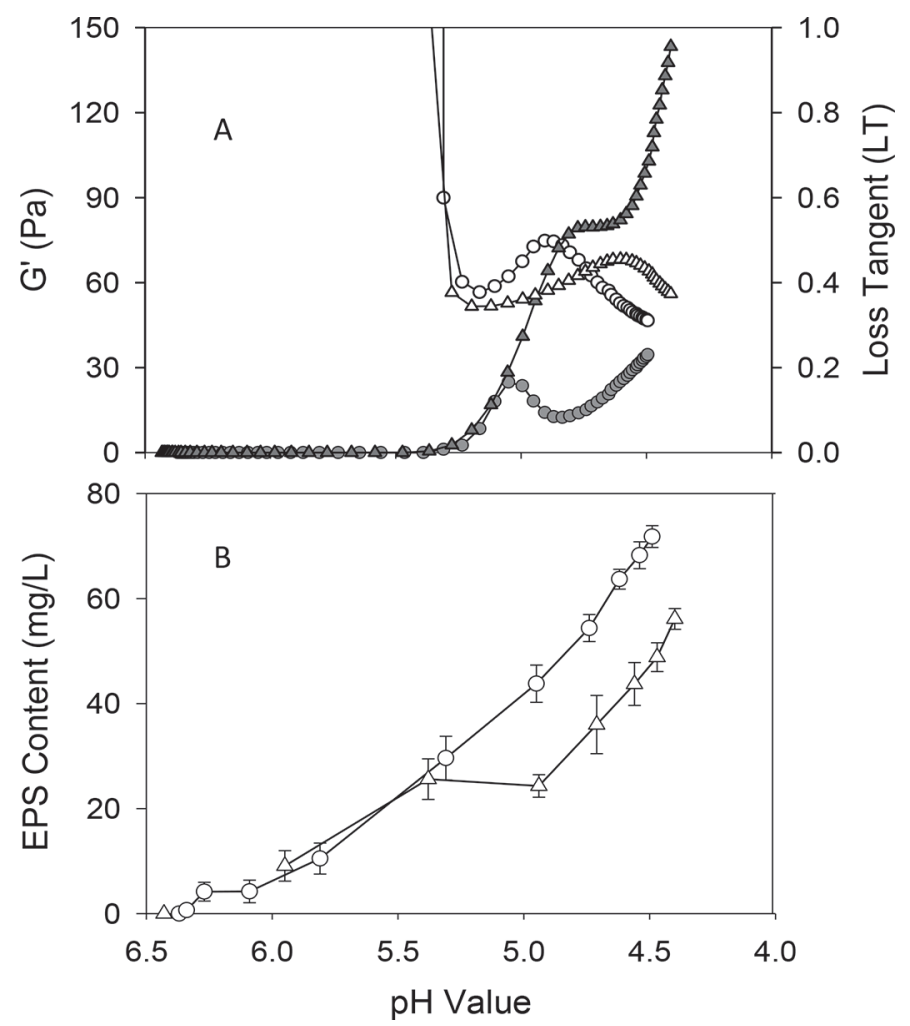

Figure 2. (A) Rheological properties of acid milk gels, and (B) exopolysaccharide (EPS) production during fermentation of milk at $40^{\circ} \mathrm{C}$ by Streptococcus thermophilus strains St-143 (O), and ST-10255y $(\triangle)$. (A) Dark gray symbols indicate storage modulus $\left(G^{\prime}\right)$, and white symbols indicate loss tangent (LT); (B) error bars indicate standard error of means. 
Table 2. Summary of rheological properties of acid gels, and yield and properties of exopolysaccharides (EPS) isolated from milk fermented by Streptococcus thermophilus strains at $40^{\circ} \mathrm{C}$

\begin{tabular}{|c|c|c|}
\hline \multirow[b]{2}{*}{ Parameter $^{1}$} & \multicolumn{2}{|c|}{ S. thermophilus strains ${ }^{2}$} \\
\hline & St-143 & ST-10255y \\
\hline $\begin{array}{l}\text { Gelation time }(\mathrm{min}) \\
\mathrm{pH} \text { at gelation } \\
\mathrm{LT}_{\mathrm{Max}} \\
\mathrm{pH} \text { at } \mathrm{LT}_{\mathrm{Max}} \\
\mathrm{G}^{\prime} \text { at } \mathrm{pH} 4.6(\mathrm{~Pa}) \\
\text { Time to reach } \mathrm{pH} 4.5(\mathrm{~min}) \\
\text { Max EPS yield }(\mathrm{mg} / \mathrm{L}) \\
\text { Molar mass of } \mathrm{EPS}^{3}\left(10^{6} \mathrm{~g} / \mathrm{mol}\right) \\
\mathrm{R}_{g} \text { of } \mathrm{EPS}^{3}(\mathrm{~nm}) \\
\mathrm{PD} \text { ratio of } \mathrm{EPS}^{3}\end{array}$ & $\begin{aligned} 152 & \pm 2^{\mathrm{a}} \\
5.26 & \pm 0.02^{\mathrm{a}} \\
0.498 & \pm 0.003^{\mathrm{a}} \\
4.9 & \pm 0.03^{\mathrm{a}} \\
26.1 & \pm 1.7^{\mathrm{b}} \\
270^{\mathrm{a}} & \\
71.3 & \pm 2.3^{\mathrm{a}} \\
1.57 & \pm 0.27^{\mathrm{a}} \\
54.0 & \pm 0.1^{\mathrm{a}} \\
1.15 & \pm 0.03^{\mathrm{a}}\end{aligned}$ & $\begin{aligned} 153 & \pm 2^{\mathrm{a}} \\
5.25 & \pm 0.03^{\mathrm{a}} \\
0.456 & \pm 0.001^{\mathrm{b}} \\
4.7 & \pm 0.02^{\mathrm{b}} \\
82.1 & \pm 4.9^{\mathrm{a}} \\
270^{\mathrm{a}} & \\
55.8 & \pm 2.8^{\mathrm{b}} \\
0.78 & \pm 0.00^{\mathrm{b}} \\
42.1 & \pm 0.1^{\mathrm{b}} \\
1.01 & \pm 0.00^{\mathrm{b}}\end{aligned}$ \\
\hline
\end{tabular}

both strains St-143 and ST-10255y (Table 2). The $\mathrm{pH}$ of gelation for both strains was $\mathrm{pH} \sim 5.25$ (Table 2). The $\mathrm{G}^{\prime}$ profile for strain St-143 exhibited an initial increase after gelation, but the $\mathrm{G}^{\prime}$ values then decreased around $\mathrm{pH} 4.9$ before increasing again at $\mathrm{pH}$ values $\leq 4.8$ (Figure 2a). The decrease in $\mathrm{G}^{\prime}$ values corresponded to the $\mathrm{pH}(\mathrm{pH} \sim 4.9)$ at which the maximum loss tangent $\left(\mathbf{L} \mathbf{T}_{\text {Max }}\right.$ ) values $(0.498)$ of the gel was also observed (Figure 2a). The $\mathrm{G}^{\prime}$ profile of milk fermented by ST-10255y exhibited a shoulder (flattening of the $\mathrm{G}^{\prime}$ profile) between $\mathrm{pH} 4.9$ and 4.6 , while at lower $\mathrm{pH}$ values $(\leq 4.6)$, it increased sharply (Figure 2a). The $\mathrm{LT}_{\text {Max }}(0.456)$ was also observed to occur at a lower $\mathrm{pH}$ values $(\mathrm{pH} 4.7)$ for the gels made with ST-10255y (Figure 2a, Table 2). For strains St-143 and ST-10255y, the $\mathrm{G}^{\prime}$ values of milk gels at $\mathrm{pH} 4.6$ were 26 and $82 \mathrm{~Pa}$ (Table 2), reaching 35 and $145 \mathrm{~Pa}$, respectively, when $\mathrm{pH}$ was 4.5 .

\section{Molar Mass of EPS During the Fermentation Period}

During fermentation, EPS was isolated without precipitation by ethanol, and the molar mass of EPS was determined in ultrafiltration extracts. Peaks referring to EPS were selected by examining both RI and UV signals. Peaks with high UV signals were considered likely because of high levels of protein contamination and were ignored. The cumulative weight fraction and molar mass plots of the EPS indicated a decrease in the molar mass values of both EPS types during fermentation (Figure 3). For the EPS isolated from strain St-143, the average molar mass of the EPS obtained at pH 5.2 during fermentation was $2.9 \times 10^{6} \mathrm{~g} / \mathrm{mol}$, which then gradually decreased to $1.6 \times 10^{6} \mathrm{~g} / \mathrm{mol}$ in the sample isolated at $\mathrm{pH} 4.5$ (Figure 4). A significant de- crease was also observed in the molar mass of EPS during fermentation by strain ST-10255y. The $\mathrm{R}_{g}$ values, which reflect the molecular size of the polysaccharides (Tuinier et al., 1999), was 56 to $42 \mathrm{~nm}$ for EPS from St-143 and ST-10255y strains, respectively (Table 2). Fermentation $\mathrm{pH}$ had no significant effect on these $\mathrm{R}_{g}$

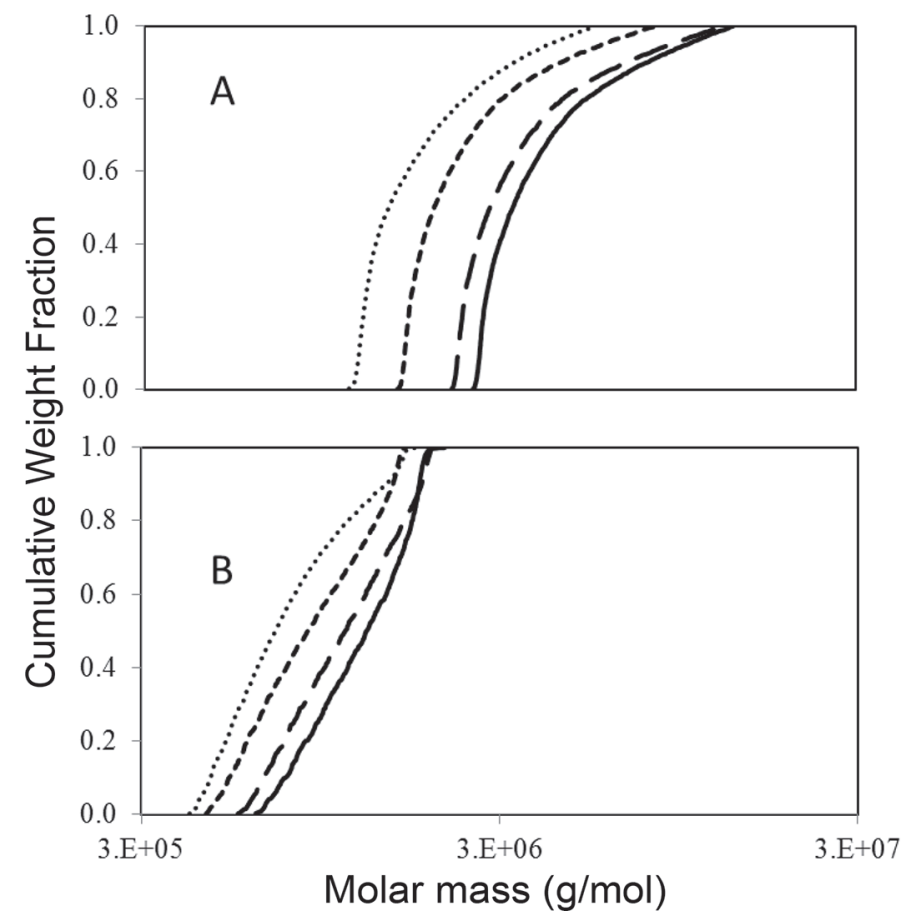

Figure 3. Cumulative molar mass profile of exopolysaccharides obtained from Streptococcus thermophilus St-143 (A) and ST-10255y (B) at different $\mathrm{pH}$ values during fermentation of milk at $40^{\circ} \mathrm{C}$, obtained by size exclusion chromatography multi-angle laser light scattering (SEC-MALLS). Solid lines $=\mathrm{pH} 5.2$; long dashed lines $=\mathrm{pH} 4.9$; short dashed lines $=\mathrm{pH} 4.7$; dotted lines $=\mathrm{pH}$ 4.5. 
values (results not shown). The polydispersity values of the EPS, calculated as the ratio of weight-average molecular weight to the number-average molecular weight, for all the EPS samples were 1.1 to 1.2 (result not shown), indicating that these isolated molecules were fairly monodisperse.

\section{DISCUSSION}

Streptococcus thermophilus strains started producing EPS when $\mathrm{pH}$ values reached $\sim 5.3$ (close to gelation) (Figure 2b). Thereafter, the amount of EPS increased until the end of fermentation ( $\mathrm{pH}$ 4.5). Most of the past studies using milk were focused on determining the final yield of EPS at the end of fermentation, so it was not clear from them when $S$. thermophilus strains produced EPS. When milk was fermented at constant $\mathrm{pH}$ of 5.5, EPS production started after $\sim 4 \mathrm{~h}$ of fermentation with $S$. thermophilus LY03, suggesting that EPS production was faster when fermentation was carried out at $\mathrm{pH}$ values close to the gelation point of milk (De Vuyst et al., 1998). In case of milk fermented without pH control, Frengova et al. (2000) reported for pure or mixed yogurt cultures of $S$. thermophilus and Lactobacillus delbrueckii ssp. bulgaricus that the production of EPS began within $1 \mathrm{~h}$ of the start of fermentation. These reports suggest that EPS synthesis does not start immediately at the initial phase (lag phase) of fermentation. It appears that EPS production may occur toward the exponential phase of growth. After 90 to $150 \mathrm{~min}$, the rate of $\mathrm{pH}$ decrease (related to bacterial

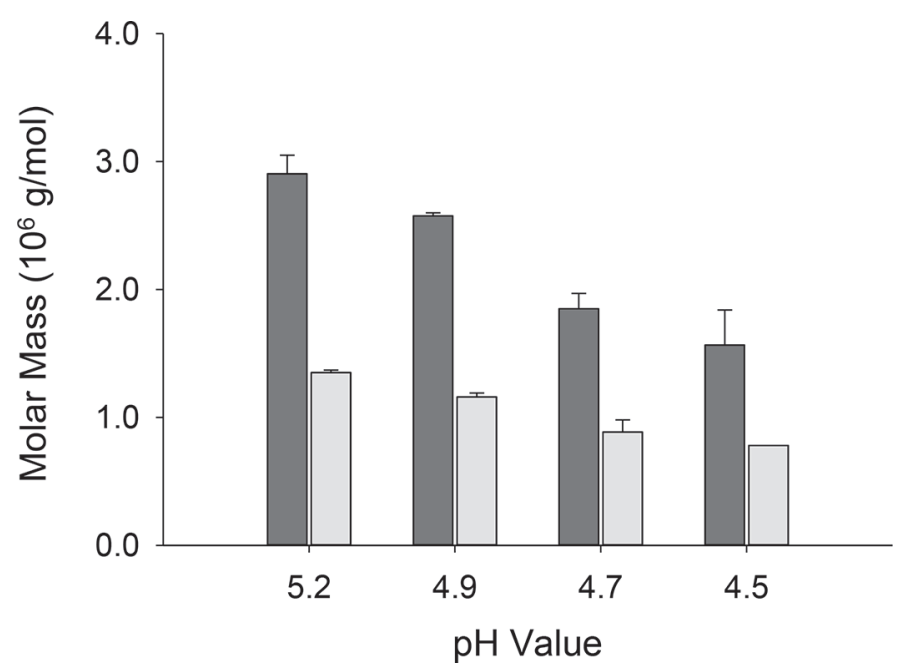

Figure 4. Molar mass of exopolysaccharides obtained from Streptococcus thermophilus strains St-143 (dark gray bars) and ST10255y (light gray bars) at different $\mathrm{pH}$ values during fermentation of milk at $40^{\circ} \mathrm{C}$. Error bars indicate standard error of means. growth rate) was the highest until milk fermentation reached $\mathrm{pH} \sim 5.3$. At that point, the actively growing bacterial cells were likely to sense stress due to the decrease in $\mathrm{pH}$, which possibly helped to promote EPS synthesis. Biosynthesis of cell wall polymers and EPS by LAB needs nucleotide sugars as precursors (De Vuyst and Degeest, 1999; Laws et al., 2001). Because active cell growth needs more energy at an early stage of fermentation, metabolism may be directed toward glycolysis, with the available nucleotide sugars mostly used for biosynthesis of cell wall polysaccharides (De Vuyst et al., 1998). Toward the end of active growth phase (near $\mathrm{pH} 5.3$ during fermentation of milk), it is possible that cell division slows down, energy requirements decline, biosynthesis of cell wall polysaccharides reduces, and more nucleotide sugars are available for EPS biosynthesis (De Vuyst et al., 1998).

The yield of EPS during fermentation of milk by $S$. thermophilus St-143 and ST-10255 increased during fermentation. The final yields of EPS for both strains were in agreement with the previously reported EPS yields for these strains. In past studies, EPS-producing S. thermophilus have been investigated for their final EPS yields in different types of media, including milk (Giraffa and Bergère, 1987; Cerning et al., 1988; Faber et al., 1998; De Vuyst et al., 2003; Vaningelgem et al., 2004; Mende et al., 2012; Pachekrepapol et al., 2017). Depending on the strains and fermentation media and conditions, reported yields of EPS produced by the $S$. thermophilus strains ranged from $8 \mathrm{mg} / \mathrm{L}$ (Pachekrepapol et al., 2017) to $290 \mathrm{mg} / \mathrm{L}$ (Vaningelgem et al., 2004). In most of the past studies, in which milk-based media were fermented at temperatures in the range of 37 to $42^{\circ} \mathrm{C}$ for extended periods, the final yield of EPS was relatively high (>100 mg/L) (De Vuyst et al., 2003; Vaningelgem et al., 2004), whereas, for relatively shorter fermentation periods, the final yield of EPS was less than $100 \mathrm{mg} / \mathrm{L}$ (Mende et al., 2012; Pachekrepapol et al., 2017). The yields of EPS from S. thermophilus St-143 and ST-10255y were reported to be 65 and $27 \mathrm{mg} \mathrm{GE} / \mathrm{kg}$, respectively, when isolated by ethanol precipitation of whey obtained from fermented milk (Pachekrepapol et al., 2017). These results indicated that the yield of EPS is higher when milk is fermented for an extended period of time. Studies have also highlighted that EPS biosynthesis is positively associated with bacterial growth (De Vuyst et al., 1998; Degeest et al., 2001). For example, EPS yield coefficients, calculated as grams of EPS produced per gram of lactose present in the medium, was maximal when cultures attained maximum specific growth rate, indicating that EPS synthesis was highly associated with bacterial growth rate (De Vuyst et al., 1998). Increased yields of 
EPS parallel to growth rate, fermentation duration, or both have also been reported in other LAB such as $L$. delbrueckii ssp. bulgaricus (Grobben et al., 1995) and Lactobacillus rhamnosus (Pham et al., 2000). Increased yields of EPS during the fermentation period of $\sim 5 \mathrm{~h}$ in our study are consistent with the trend for reported growth-dependent EPS production in S. thermophilus as well as other LAB.

The amount of EPS isolated from a medium depends on the complexity of the medium and the method used for isolation. Methods based on ultrafiltration (Goh et al., 2005), TCA precipitation of protein and subsequent EPS precipitation by ethanol or acetone (Cerning et al., 1994), and enzymatic digestion and TCA precipitation of protein (Kimmel et al., 1998) have all been used for isolation of EPS from milk. The presence of protein $(\sim 3.5 \%)$ in milk makes it a more complex medium for EPS isolation; however, the quantity of EPS synthesized by $S$. thermophilus in fermented milk is very low $(<300 \mathrm{mg} / \mathrm{L})$ (De Vuyst et al., 2003; Mende et al., 2012) in comparison with the higher concentration $(>45,000$ $\mathrm{mg} / \mathrm{L}$ ) of the native milk carbohydrate (lactose) (Fox, 2009). Therefore, an ideal method of EPS isolation should be efficient to prevent excessive loss of EPS during the isolation process and to effectively remove small sugars such lactose, glucose, and galactose (Rimada and Abraham, 2003). The method for isolation of EPS used in this study had a recovery efficiency of 44 to $61 \%$, depending on the concentration of added dextran (a model EPS) in milk (Table 1), which was higher than reported past results. Goh et al. (2005) reported 27 to $30 \%$ recovery of dextran by ethanol precipitation from milk permeate. Methods that solubilize EPS at an early stage of isolation process by heating of milk, avoid TCA precipitation of protein, and use multiple steps of ethanol precipitation resulted in increased EPS recovery (Rimada and Abraham, 2003). Heating of milk before protein removal and multiple ethanol precipitation steps might have contributed to the higher $(\sim 50 \%)$ recovery of added EPS in this study.

The molar mass of EPS significantly decreased during fermentation as $\mathrm{pH}$ decreased from 5.2 to 4.5 (Figure 4). No previous published reports exist (that we are aware of) on the molar mass of EPS isolated at various time points during fermentation of milk. However, the results for the overall range of molar mass obtained for EPS in this study are in general agreement with previous studies. Past studies showed that the molar mass of EPS produced by $S$. thermophilus ranged from $1 \times 10^{6}$ to $5 \times 10^{6} \mathrm{~g} / \mathrm{mol}$. One of the earliest report on molar mass of isolated EPS samples from $S$. thermophilus strains CNCMI 733, 734, and 735 was about $1.0 \times$ $10^{6} \mathrm{~g} / \mathrm{mol}$ (Doco et al., 1990). The molar mass of EPS synthesized by $S$. thermophilus strains SFi39 and SFi12 in milk medium was higher than $2 \times 10^{6} \mathrm{~g} / \mathrm{mol}$ when analyzed by gel filtration chromatography (Lemoine et al., 1997). Milk fermented by 2 EPS-producing $S$. thermophilus strains (Rs and Sts) yielded EPS of molar mass that ranged from $2.6 \times 10^{6}$ to $3.7 \times 10^{6} \mathrm{~g} / \mathrm{mol}$ when analyzed by permeation chromatography combined with static light scattering and RI (Faber et al., 1998). Considerable variation has also been reported in the molar mass of EPS isolated from the same strain. For example, Mende et al. (2012) reported that the molar mass of EPS from $S$. thermophilus strain St-143 was $4.3 \times 10^{6} \mathrm{~g} / \mathrm{mol}$ when analyzed by gel filtration chromatography, whereas molar mass of EPS from the same strain was reported as $1.4 \times 10^{6} \mathrm{~g} / \mathrm{mol}$ when analyzed by SEC-MALLS (Pachekrepapol et al., 2017).

Notably, in most of those studies, EPS was isolated from milk after the fermentation was ended. Information on the molar mass of EPS samples isolated from milk at intermediate fermentation periods is not available. However, some indications exist that EPS molecules may undergo some enzymatic hydrolysis if the EPS remain in the fermentation medium for an extended period of time. Cerning et al. (1988) discussed the possibility of the production of exocellular glycohydrolases during fermentation of milk by $S$. thermophilus that may be activated during fermentation, which would result in the hydrolysis of EPS. A decrease in the molar mass of EPS from $S$. thermophilus (BCRC 14085) during the $\mathrm{pH}$ controlled fermentation ( $\mathrm{pH} 5.0$ ) of skim milk for $>12 \mathrm{~h}$ also indicated the possibility of enzymatic degradation of EPS (Lin and Chien, 2007). Frengova et al. (2000) also reported a reduction in the quantity of EPS from $S$. thermophilus during refrigerated storage of fermented milk, possibly due to hydrolysis of EPS by glycohydrolase enzymes. The presence of EPS-hydrolyzing glycohydrolase enzymes $\alpha$-glucosidase, $\beta$-glucuronidase, $\beta$-D-glucosidase, $\alpha$-D-galactosidase, $\beta$-D-galactosidase, and $\alpha$-L-rhamnosidase in the cell extract of L. rhamnosus were also reported by Pham et al. (2000). In our study, some partial hydrolysis of EPS during fermentation might possibly have occurred causing the decrease in molar masses. Another likely possibility is that the EPS isolated at different $\mathrm{pH}$ values during fermentation could have varying levels of contamination by protein, which might have affected the estimated molar mass of the isolated EPS.

Milk fermented by both strains gelled when the $\mathrm{pH}$ of milk was $\sim 5.25$ (Table 2). The $\mathrm{pH}$ of gelation was slightly higher than previous results for these $S$. thermophilus strains ( $\mathrm{pH}$ 5.1-5.2) reported by Mende et al. (2012). Small variations in the gelation $\mathrm{pH}$ of milk during fermentation can be caused by differences in the 
extent of whey protein denaturation during preheating of milk as well as the level of starter inoculation (Lucey et al., 1997; Lee and Lucey, 2004). Severe heating of milk under conditions that cause denaturation of most whey proteins, particularly $\beta$-lactoglobulin, helps milk to gel at $\mathrm{pH}$ values close to the isoelectric $\mathrm{pH}(\mathrm{pH} \sim 5.3)$ of $\beta$-lactoglobulin (Lucey and Singh, 2003).

Milk gelled by $S$. thermophilus strain St-143 showed a significant decrease in the $\mathrm{G}^{\prime}$ curve between $\mathrm{pH}$ values 5.1 and 4.9 , whereas the gel fermented by $S$. thermophilus strain ST-10255y showed only a shoulder or flattening in the $\mathrm{G}^{\prime}$ curve between $\mathrm{pH} 5.0$ and 4.7 (Figure $2 a)$. An increase in $G^{\prime}$ values after gelation and a slight shoulder in the $G^{\prime}$ curve, before increasing again at low $\mathrm{pH}$ values is a typical rheological pattern of fermented milk gels made from heated milk (Lucey et al., 1998b; Lucey, 2002; Peng et al., 2009). When milk pH reaches $\sim 5.3$, casein particles bridged by denatured whey proteins initiate gelation. In the $\mathrm{pH}$ region from 5.0 to 5.2 , gel stiffness may decrease mainly because colloidal calcium phosphate (CCP) solubilizes. The CCP nanoclusters are important internal crosslinking material within the casein particles. A decrease in casein particles' internal crosslinking can lead to a decrease in gel stiffness (Lucey, 2002; Lucey and Singh, 2003). Gel stiffness increases again at lower $\mathrm{pH}$ values approaching the isoelectric point of casein, leading to stronger casein-casein interactions (Lucey, 2002; Lucey and Singh, 2003). With the solubilization of CCP and the weakening of initial (weak) gel network, the LT values increase to reach a maximum near pH 5.0 (Lucey, 2002). Higher $\mathrm{LT}_{\mathrm{Max}}$ values indicate greater bond mobility in the gel network that could promote more bond relaxation and greater network rearrangements (Lucey et al., 1997; Lucey and Singh, 2003). The gel formed by strain St143 had a higher $\mathrm{LT}_{\mathrm{Max}}$ value compared with gel formed by strain ST-10255y. A higher $\mathrm{LT}_{\text {Max }}$ value for the gel made by strain St-143 could have resulted in more extensive rearrangement of the network, contributing to a decrease in $\mathrm{G}^{\prime}$ values in that $\mathrm{pH}$ region. Because the $\mathrm{LT}_{\text {Max }}$ occurred at a higher $\mathrm{pH}$ value $(\mathrm{pH} 4.9)$ in gels made with St-143 (Table 2), these newly formed gels were possibly more prone to extensive rearrangements that ultimately resulted in a sharper decrease in the $\mathrm{G}^{\prime}$ curve compared with the gels made with ST-10255y, for which the $\mathrm{LT}_{\text {Max }}$ occurred at pH 4.7 (Figure 2a).

Because the milk composition, heat treatment, fermentation conditions, and gelation $\mathrm{pH}$ values were all identical in these samples, the observed differences in rheological properties during the formation of gels made by strains St-143 and ST-10255y were likely related to the properties of EPS produced by these 2 strains. Polysaccharides of higher molar mass and size are less likely to be compatible with proteins and may promote greater depletion flocculation type effects (de Kruif and Tuinier, 2001; Corredig et al., 2011; Pachekrepapol et al., 2014). The molar mass of EPS produced by strain St-143 was almost double the molar mass of EPS produced by ST-10255y, and the $\mathrm{R}_{g}$ value was also larger (Table 2). It is unclear why the gels made with St-143 had a higher value of $\mathrm{LT}_{\mathrm{Max}}$ that also occurred at a higher $\mathrm{pH}$. Because the EPS concentration was also significantly higher for strain St-143 in the $\mathrm{pH}$ region where the $\mathrm{LT}_{\text {Max }}$ was observed, we speculate that the EPS produced by strain St-143 could have promoted more incompatibility with the protein network, which could also have contributed to the observed decrease in $\mathrm{G}^{\prime}$ values (Figure 2a).

Folkenberg (2005) studied the microstructures of acid gels and reported that the EPS from strain St-143 was likely incompatible with the protein in the gel network because EPS was mostly observed in the pores (serum phase) of the network. On the other hand, they considered that the EPS from strain ST-10255y was co-located in the network. The EPS produced by strains St-143 and ST-10255y are also different in their structure. The repeating unit of EPS produced by ST-10255y had 4 sugars (2 $\beta$-galactose, $1 \alpha$-glucose, and $1 \mathrm{~N}$-acetylgalactosamine), 3 in a linear chain and 1 branched. Sugars in the linear chain were connected by $\beta(1 \rightarrow 3)$ linkages. On the other hand, the EPS from strain St-143 had 6 sugars in its repeating units, mainly joined by $\beta(1 \rightarrow 4)$ linkages (Pachekrepapol et al., 2017). The role of types of glycosidic linkages on the physical properties of EPS is not well understood. However, it has previously been suggested that carbohydrate polymers with $\beta(1 \rightarrow 4)$ linked structures were stiffer than with $\beta(1 \rightarrow 3)$ linked structures (Welman and Maddox, 2003). Less flexible $\beta(1 \rightarrow 4)$ EPS polymers in St-143 samples may have possibly caused more localized phase separation in the weak initial protein network.

\section{CONCLUSIONS}

The modified Enikeev method for EPS determination in fermented milk that was used in this study could be completed in less than $1 \mathrm{~d}$ and was able to recover $\sim 60 \%$ of added EPS. The 2 strains of $S$. thermophilus studied produced a significant amount of EPS only after $\sim 150$ min of fermentation, which was around the time when milk started to gel. When fermentation had progressed further, the quantities of EPS increased, but the molar mass of EPS slightly decreased. The strain St-143 produced higher concentrations of EPS that had higher molar mass, larger $\mathrm{R}_{g}$ values, and longer repeating unit structures, which resulted in weaker acid gels in comparison with the gels made by strain ST-10255y. 


\section{ACKNOWLEDGMENTS}

The article is based on the work funded by USDA National Institute of Food and Agriculture, Hatch project (WIS01650; Washington, DC).

\section{REFERENCES}

Broadbent, J. R., D. J. McMahon, D. Welker, C. Oberg, and S. Moineau. 2003. Biochemistry, genetics, and applications of exopolysaccharide production in Streptococcus thermophilus: A review. J. Dairy Sci. 86:407-423.

Cerning, J., C. Bouillanne, M. Desmazeaud, and M. Landon. 1988. Exocellular polysaccharide production by Streptococcus thermophilus. Biotechnol. Lett. 10:255-260.

Cerning, J., C. Renard, J. F. Thibault, C. Bouillanne, M. Landon, M. Desmazeaud, and L. Topisirovic. 1994. Carbon source requirements for exopolysaccharide production by Lactobacillus casei CG11 and partial structure analysis of the polymer. Appl. Environ. Microbiol. 60:3914-3919.

Corredig, M., N. Sharafbafi, and E. Kristo. 2011. Polysaccharide-protein interactions in dairy matrices, control and design of structures. Food Hydrocoll. 25:1833-1841.

de Kruif, C. G., and R. Tuinier. 2001. Polysaccharide protein interactions. Food Hydrocoll. 15:555-563.

De Vuyst, L., and F. De Vin. 2007. Eopolysaccharides from lactic acid bacteria. Pages 477-519 in Comprehensive Glycoscience. P. K. Johannis, ed. Elsevier, Oxford, UK.

De Vuyst, L., F. De Vin, F. Vaningelgem, and B. Degeest. 2001. Recent developments in the biosynthesis and applications of heteropolysaccharides from lactic acid bacteria. Int. Dairy J. 11:687-707.

De Vuyst, L., and B. Degeest. 1999. Heteropolysaccharides from lactic acid bacteria. FEMS Microbiol. Rev. 23:153-177.

De Vuyst, L., F. Vanderveken, S. Van de Ven, and B. Degeest. 1998. Production by and isolation of exopolysaccharides from Streptococcus thermophilus grown in a milk medium and evidence for their growth-associated biosynthesis. J. Appl. Microbiol. 84:1059-1068.

De Vuyst, L., M. Zamfir, F. Mozzi, T. Adriany, V. Marshall, B. Degeest, and F. Vaningelgem. 2003. Exopolysaccharide-producing Streptococcus thermophilus strains as functional starter cultures in the production of fermented milks. Int. Dairy J. 13:707-717.

Degeest, B., F. Vaningelgem, A. P. Laws, and L. De Vuyst. 2001. UDP-N-acetylglucosamine 4-epimerase activity indicates the presence of N-acetylgalactosamine in exopolysaccharides of Streptococcus thermophilus strains. Appl. Environ. Microbiol. 67:3976-3984.

di Cagno, M., T. Terndrup Nielsen, K. Lambertsen Larsen, J. Kuntsche, and A. Bauer-Brandl. 2014. $\beta$-Cyclodextrin-dextran polymers for the solubilization of poorly soluble drugs. Int. J. Pharm. 468:258-263.

Doco, T., J.-M. Wieruszeski, B. Fournet, D. Carcano, P. Ramos, and A. Loones. 1990. Structure of an exocellular polysaccharide produced by Streptococcus thermophilus. Carbohydr. Res. 198:313321.

Dubois, M., K. A. Gilles, J. K. Hamilton, P. Rebers, and F. Smith. 1956. Colorimetric method for determination of sugars and related substances. Anal. Chem. 28:350-356.

Enikeev, R. 2012. Development of a new method for determination of exopolysaccharide quantity in fermented milk products and its application in technology of kefir production. Food Chem. 134:24372441.

Faber, E. J., P. Zoon, J. P. Kamerling, and J. F. G. Vliegenthart. 1998. The exopolysaccharides produced by Streptococcus thermophilus RS and STS have the same repeating unit but differ in viscosity of their milk cultures. Carbohydr. Res. 310:269-276.

Folkenberg, D. M. 2005. Modifying yoghurt texture by exopolysaccharide producing lactic acid bacteria. PhD Thesis. The Royal Veterinary and Agriculture Univ., Frederiksberg, Denmark.
Fox, P. 2009. Lactose: Chemistry and properties. Pages 1-15 in Advanced Dairy Chemistry. Vol 3. 3rd ed. P. F. Fox and P. L. H. McSweeney, ed. Springer, New York, NY.

Frengova, G. I., E. D. Simova, D. M. Beshkova, and Z. I. Simov. 2000. Production and monomer composition of exopolysaccharides by yogurt starter cultures. Can. J. Microbiol. 46:1123-1127.

Giraffa, G., and J.-L. Bergère. 1987. Nature du caractère épaississant de certaines souches de Streptococcus thermophilus, étude préliminaire. Lait 67:285-297.

Goh, K. K. T., D. R. Haisman, R. H. Archer, and H. Singh. 2005. Evaluation and modification of existing methods for the quantification of exopolysaccharides in milk-based media. Food Res. Int. 38:605-613.

Grobben, G. J., J. Sikkema, M. R. Smith, and J. A. M. de Bont. 1995. Production of extracellular polysaccharides by Lactobacillus delbrueckii ssp. bulgaricus NCFB 2772 grown in a chemically defined medium. J. Appl. Bacteriol. 79:103-107.

Kimmel, S. A., R. F. Roberts, and G. R. Ziegler. 1998. Optimization of exopolysaccharide production by Lactobacillus delbrueckii ssp. bulgaricus RR grown in a semidefined medium. Appl. Environ. Microbiol. 64:659-664.

Laws, A., Y. Gu, and V. Marshall. 2001. Biosynthesis, characterisation, and design of bacterial exopolysaccharides from lactic acid bacteria. Biotechnol. Adv. 19:597-625.

Lee, W. J., and J. A. Lucey. 2004. Structure and physical properties of yogurt gels: Effect of inoculation rate and incubation temperature. J. Dairy Sci. 87:3153-3164.

Lemoine, J., F. Chirat, J.-M. Wieruszeski, G. Strecker, N. Favre, and J.-R. Neeser. 1997. Structural characterization of the exocellular polysaccharides produced by Streptococcus thermophilus Sfi39 and Sfi12. Appl. Environ. Microbiol. 63:3512-3518.

Leroy, F., and L. De Vuyst. 2016. Advances in production and simplified methods for recovery and quantification of exopolysaccharides for applications in food and health. J. Dairy Sci. 99:3229-3238.

Lin, T. Y., and M. F. C. Chien. 2007. Exopolysaccharides production as affected by lactic acid bacteria and fermentation time. Food Chem. 100:1419-1423.

Low, D., J. A. Ahlgren, D. Horne, D. J. McMahon, C. J. Oberg, and J. R. Broadbent. 1998. Role of Streptococcus thermophilus MR$1 \mathrm{C}$ capsular exopolysaccharide in cheese moisture retention. Appl. Environ. Microbiol. 64:2147-2151.

Lucey, J. A. 2002. Formation and physical properties of milk protein gels. J. Dairy Sci. 85:281-294.

Lucey, J., and H. Singh. 2003. Acid coagulation of milk. Pages 10011025 in Advanced Dairy Chemistry. Vol 1. 2nd ed. P. F. Fox and P. L. H. McSweeney, ed. Springer, New York, NY.

Lucey, J., M. Tamehana, H. Singh, and P. Munro. 1998a. A comparison of the formation, rheological properties and microstructure of acid skim milk gels made with a bacterial culture or glucono- $\delta$ lactone. Food Res. Int. 31:147-155.

Lucey, J. A., M. Tamehana, H. Singh, and P. A. Munro. 1998b. Effect of interactions between denatured whey proteins and casein micelles on the formation and rheological properties of acid skim milk gels. J. Dairy Res. 65:555-567.

Lucey, J. A., C. T. Teo, P. A. Munro, and H. Singh. 1997. Rheological properties at small (dynamic) and large (yield) deformations of acid gels made from heated milk. J. Dairy Res. 64:591-600.

Marshall, V. M., H. Dunn, M. Elvin, N. McLay, Y. Gu, and A. P. Laws. 2001. Structural characterisation of the exopolysaccharide produced by Streptococcus thermophilus EU 20. Carbohydr. Res. 331:413-422.

Mende, S., C. Mentner, S. Thomas, H. Rohm, and D. Jaros. 2012. Exopolysaccharide production by three different strains of Streptococcus thermophilus and its effect on physical properties of acidified milk. Eng. Life Sci. 12:466-474.

Mullin, W. J., and D. B. Emmons. 1997. Determination of organic acids and sugars in cheese, milk and whey by high performance liquid chromatography. Food Res. Int. 30:147-151.

Pachekrepapol, U., D. S. Horne, and J. Lucey. 2014. Interactions between acidified dispersions of milk proteins and dextran or dextran sulfate. J. Dairy Sci. 97:5371-5382. 
Pachekrepapol, U., J. A. Lucey, Y. Gong, R. Naran, and P. Azadi. 2017. Characterization of the chemical structures and physical properties of exopolysaccharides produced by various Streptococcus thermophilus strains. J. Dairy Sci. 100:3424-3435.

Peng, Y., D. S. Horne, and J. Lucey. 2009. Impact of preacidification of milk and fermentation time on the properties of yogurt. J. Dairy Sci. 92:2977-2990.

Pham, P. L., I. Dupont, D. Roy, G. Lapointe, and J. Cerning. 2000. Production of exopolysaccharide by Lactobacillus rhamnosus $\mathrm{R}$ and analysis of its enzymatic degradation during prolonged fermentation. Appl. Environ. Microbiol. 66:2302-2310.

Rimada, P. S., and A. G. Abraham. 2003. Comparative study of different methodologies to determine the exopolysaccharide produced by kefir grains in milk and whey. Lait 83:79-87.

Ruas-Madiedo, P., and C. G. de los Reyes-Gavilán. 2005. Methods for the screening, isolation, and characterization of exopolysaccharides produced by lactic acid bacteria. J. Dairy Sci. 88:843-856.

Tuinier, R., P. Zoon, M. C. Stuart, G. Fleer, and C. De Kruif. 1999. Concentration and shear-rate dependence of the viscosity of an exocellular polysaccharide. Biopolymers 50:641-646.
Vaningelgem, F., M. Zamfir, F. Mozzi, T. Adriany, M. Vancanneyt, J. Swings, and L. De Vuyst. 2004. Biodiversity of exopolysaccharides produced by Streptococcus thermophilus strains is reflected in their production and their molecular and functional characteristics. Appl. Environ. Microbiol. 70:900-912.

Wang, T., and J. A. Lucey. 2003. Use of multi-angle laser light scattering and size-exclusion chromatography to characterize the molecular weight and types of aggregates present in commercial whey protein products. J. Dairy Sci. 86:3090-3101.

Wehr, M. H., and J. A. Frank. 2004. Standard Methods for the Examination of Dairy Products. 17th ed. American Public Health Association, Washington, DC.

Welman, A. D., and I. S. Maddox. 2003. Exopolysaccharides from lactic acid bacteria: Perspectives and challenges. Trends Biotechnol. $21: 269-274$. 